\title{
Land Evaluation of Eastem Suez Canal, Egypt Using Remote Sensing and GIS
}

\author{
Ahmed S. Abuzaid" and Mohamed E. Fadl ${ }^{*}$ \\ ${ }^{I}$ Soil and Water Department, Faculty of Agriculture, Benha University and \\ ${ }^{2}$ Scientific Training and Continuous Studies Division, National Authority for \\ Remote Sensing and Space Sciences (NARSS), Cairo, Egypt .
}

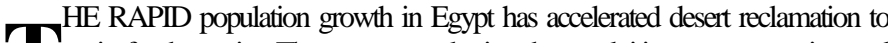
attain food security. The present work aimed at exploiting remote sensing and GIS for assessing land capability and crop suitability of soils located on the eastem side of Suez Canal, Egypt. The studied soils occupy $220.7 \mathrm{~km}^{2}$ between longitudes $32^{\circ} 24^{\prime} 1^{\prime \prime}$ to $32^{\circ} 29^{\prime} 37^{\prime \prime} \mathrm{E}$ and latitude $30^{\circ} 29^{\prime} 47^{\prime \prime}$ to $30^{\circ} 42^{\prime} 45^{\prime \prime} \mathrm{N}$. The sand sheet is the only landform covering the area, including three units; low, moderate and high. The soils are classified as Typic Torripsamments, with sand being the dominant texture class. The land capability spatial model (LCSM) showed that the fair soils occupy an $208.7 \mathrm{~km}^{2}$, representing $94.6 \%$ of the total area, while the poor soils occupy $12.0 \mathrm{~km}^{2}$ and represent $5.4 \%$ of the total area. Soil texture is the limiting factor for land capability. The Applied System for Land Evaluation (ASLE) software was used for assessing land suitability for 12 crops; alfalfa, peanut, sugar beet, wheat, onion, tomato, watermelon, citus, date palm, fig, grape, and olives. The clay content is the limiting factor. The soils would be suitable (S2) and marginally suitable (S3) for the selected crops. The most recommended crops would be peanut, tomato, and date palm, as the soils appeared suitable for their requirements.
\end{abstract}

Keywords: Land capability, Land suitability, Eastern Suez Canal, Remote sensing, GIS, ASLE.

One of the most significant indices determining agricultural progress is food security (Vink, 2012). The ability for securing food production will remain a global challenge for the next years due to the ever-increasing population and consumption growth that generate a fierce competition on land, water and energy (Godfray et al., 2010). This is vital in the developing countries, where a large portion of the future population growth is expected (Byrnes and Bumb, 1998). Egypt is one of the most heavily populated countries in the world, where about 90 million people live on about $4 \%$ of the total area of the country (El-Ramady et al., 2013). Nearly all of such area is arable land lying along the banks of the Nile and its Delta(Darwish et al., 2013); and it is threatened by urbanization (Shalaby and Moghanm, 2015). Hence, the Egyptian government has adopted a policy of encouraging reclamation of desert lands to expand the area of arable land (Adriansen, 2009). Agriculture depends mainly upon adequate irrigation and suitable soils (Lawrence et al., 2002). Thus, defining the proper land for a certain agricultural activity is needed to help decision makers in allocating highly suitable lands for such objective (Kalogirou, 2002).

Preservation of soil resources and optimal crop production requires devoting the most suitable land to a specific use (Sharififar, 2012). The process of assessing land performance over time when used for a particular purpose is known as 'land evaluation' (Bacic, 2008). It is a system of appraisal which facilitates sustainable management of land resources by 
interpreting benefits and detriments of land use (FAO, 2007). Land capability is the fitness of a given type of land for a nonspecific kind of land use (de la Rosa and van Diepen, 2002). Land suitability as defined by the FAO Framework for Land Evaluation (FAO, 1976) is "the fitness of a certain type of land for a defined use". The high capacity for producing food, fiber, and other agriculture products remains the vital aim for agricultural expansion over barren lands (Mueller et al., 2010). Crop production is a result of many factors including regional climate, land properties, socioeconomic resources, management, market, and other human activities (Li et al., 2011). The current study was carried out on lands east of the Suez Canal, Egypt to assess their capability and suitability based on land resources and soil physiochemical properties. Such assessment would help decision makers in planning to achieve sustainable agriculture.

\section{Materials and Methods}

\section{The studied area}

The studied area covers $220.7 \mathrm{~km}^{2}$ located east of Suez Canal (Fig. 1) between and $32^{\circ}$ $24^{\prime} 1^{\prime \prime}$ to $32^{\circ} 29^{\prime} 37^{\prime \prime} \mathrm{E}$ and $30^{\circ} 29^{\prime} 47^{\prime \prime}$ to $30^{\circ} 42^{\prime} 45^{\prime \prime} \mathrm{N}$. The soils are young Aeolian Quaternary deposits of late Pleistocene to Holocene era, forming sand sheets and/or sand dunes physiographic units (Mohamed et al., 2013). The total annual precipitation is 38.3 mm year ${ }^{-1}$. Temperature reaches $36.22^{\circ} \mathrm{C}$ in July and decreases to $8.0^{\circ} \mathrm{C}$ in December with a mean annual value of $22.1{ }^{\circ} \mathrm{C}$. The relative humidity ranges between $65.4 \%$ in December and $51.6 \%$ in May, with a mean value of $59.8 \%$. The soil temperature regime is Hyperthermic and the soil moisture regime is Torric.

\section{Remote sensing and GIS works}

Landsat 8 satellite image (path 176, row 39) was acquired on 21-04-2016. The ENVI 5.1 software (ITT, 2014) was used for digital image processing. The image was geometrically corrected and rectification method (image for map) was followed. The geometric model used in the rectification process was second order polynomial, and the resampling method is the nearest neighbor method. The image was stretched, smoothly filtered, and its histograms were matched for its rectification and restoration according to Lillesand and Kiefer (2007). A digital elevation model (DEM), acquired from the Shuttle Radar Topographic Mission (SRTM) on 21-4-2016, was used as the source data for elevation heights of the study area (Fig. 2). The geomorphologic map was produced using the processed Landsat 8 image and the DEM. GIS works were performed to produce base, geomorphic, capability and suitability maps of the studied area using Arc GIS 10.2.2 software (ESRI, 2014).

\section{Field and laboratory works}

Fourteen soil profiles representing the studied area were made with a depth of $150 \mathrm{~cm}$. The Global Positioning System (Garmin GPS $72 \mathrm{H}$ ) was used for identifying the exact locations of soil profiles in the field which were plotted on the map (Fig. 3). Morphologic features were described according to the FAO Guidelines (FAO, 2006). Forty-two soil samples were collected from the different horizons for analyses. The soil samples were air dried, crushed and passed through a 2-mm sieve. Chemical and physical analyses were performed according to the standard methods outlined by Estefan et al. (2013).

Egypt. J. Soil Sci. 56, No. 3 (2016) 


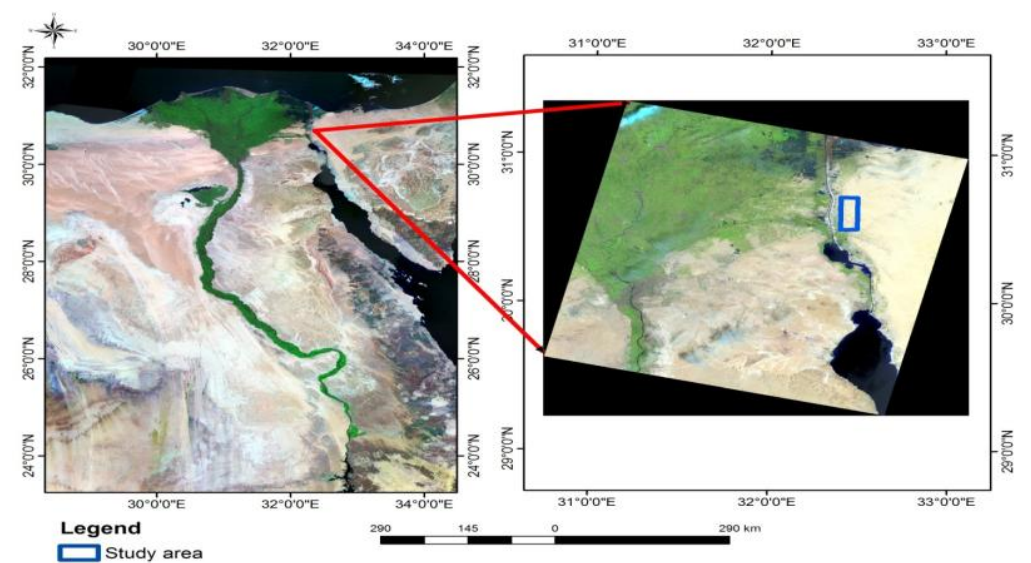

Fig. 1. Location maps of the study area.

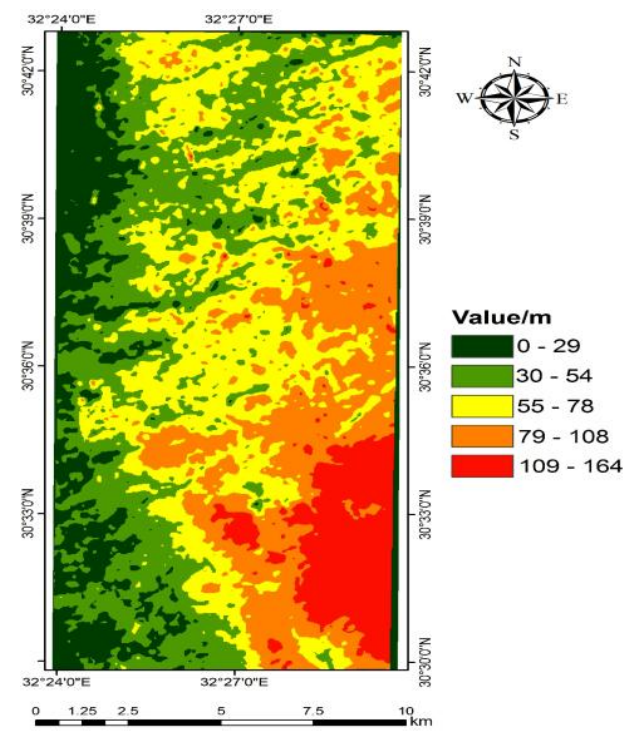

\section{Land evaluation}

Fig. 2. Digital elevation model (DEM) of the studied area.

This procedure was done using two systems. The first system is land capability classification based on the FAO Framework for Land Evaluation (FAO, 1976). Soil texture, soil depth, calcium carbonate status, gypsum content, EC, exchangeable sodium percent (ESP), drainage, and slope were inputted in the Arc GIS 10.2.2 software to design land capability model whereby capability map was produced. Also, the Applied System for Land Evaluation (ASLE) software which has been developed by Ismail et al. (2001) was used for classification based on soil properties as inputs. The second system is land suitability which was done using ASLE software based on the ratings of crop requirements proposed by Sys et al. (1993). Factors influencing land suitability for specific crop are the physical properties of clay content, profile depth, land form, level of surface and slope determine the soil-water relationship. The 
chemical properties of $\mathrm{pH}, \mathrm{CaCO}_{3}$, gypsum, $\mathrm{CEC}$, ESP and salinity determine fertility of soil. The capability and suitability classes are shown in Table 1 .

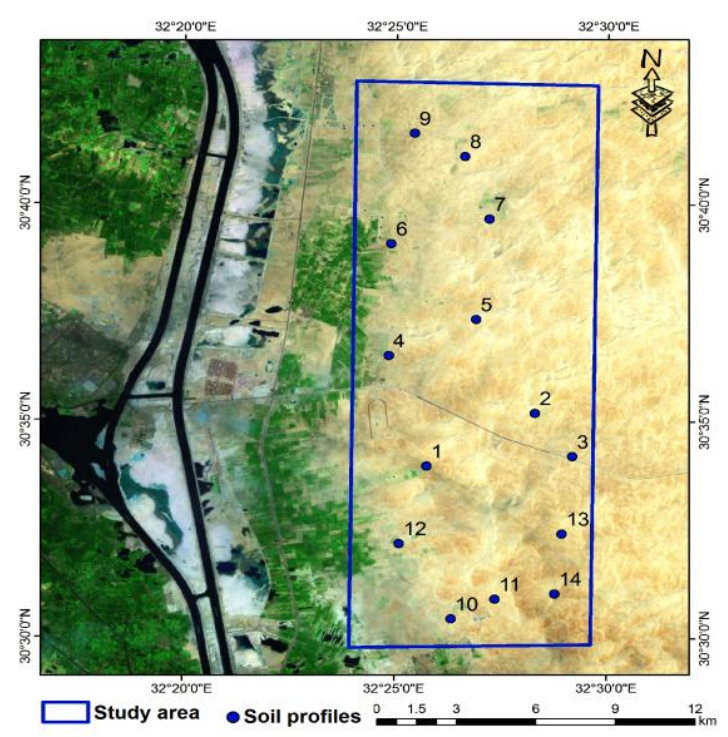

Fig. 3. Locations of soil profiles representing the study area.

TABLE 1. The ASLE capability and suitability indices and classes.

\begin{tabular}{|c|c|c|c|c|l|}
\hline $\begin{array}{c}\text { Capability } \\
\text { index }\end{array}$ & Class & Description & $\begin{array}{c}\text { Suitability } \\
\text { index }\end{array}$ & $\begin{array}{c}\text { Clas } \\
\text { s }\end{array}$ & \multicolumn{1}{|c|}{ Description } \\
\hline$>80$ & C1 & Excellent & $>80$ & S1 & Highly suitable \\
\hline $80-60$ & C2 & Good & $80-60$ & S2 & Suitable \\
\hline $60-40$ & C3 & Fair & $60-40$ & S3 & Moderately suitable \\
\hline $40-20$ & C4 & Poor & $40-20$ & S4 & Marginally suitable \\
\hline $20-10$ & C5 & Very poor & $20-10$ & Ns1 & Currently not suitable \\
\hline$<10$ & C6 & Non-agriculture & $<10$ & Ns2 & Permanentlynotsuitable \\
\hline
\end{tabular}

Geomorphology

\section{Results and Discussions}

Interpretation of satellite image and DEM is used to identify the geomorphologic features of an area. This procedure (which is the most common, economic and versatile advanced technology) offers the reality to the ground observation. Analyzing the main landscape which is extracted from the satellite image through the DEM and field survey enables recognizing and delineating the geomorphic units in the studied area. The results revealed that the main landform in the area is the sand sheet, which has been derived mainly from the Aeolian deposits that are scattered over the whole area. The sand sheet could be divided into three mapping unit (Fig. 4); low, moderate and high, covering 105.6, 103.1 and $12.0 \mathrm{~km}^{2}$, respectively. Soil profiles Nos. 10,11 and 13 were chosen as modal representative profiles for the three mapping unit; low, moderate and high sand sheet, respectively to be inputted in the Arc GIS 10.2.2 for soil mapping.

Egypt. J. Soil Sci. 56, No. 3 (2016) 


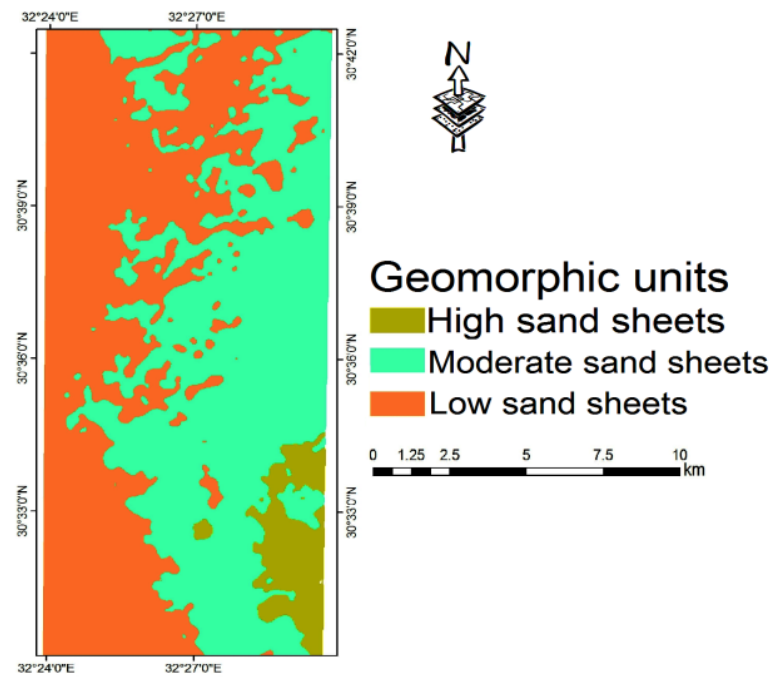

Fig. 4. Geomorphic map of the study area.

Soils of the studied area

Table 2 shows the weighted mean values of soil characteristics and $\mathrm{pH}$ of the surface horizons. Soil $\mathrm{pH}$ varied between 7.83 and 8.53 , indicating moderately to strongly alkaline reaction. Soil salinity varied from non-saline to slightly saline as EC values ranged from 0.79 to $6.14 \mathrm{dS} \mathrm{m}^{-1}$. Organic matter content was low and did not exceed $1.10 \mathrm{~g} \mathrm{~kg}^{-1}$ due to the absence of natural vegetation and the aridity conditions. Values of calcium carbonate and gypsum contents varied between $0.62-1.12$ for the former and $0.60-1.38 \mathrm{~g} \mathrm{~kg}^{-1}$ for the later. The CEC was low and ranged from 3.87 to $5.68 \mathrm{cmolc} \mathrm{kg}^{-1}$ due to low organic matter and clay contents. The soils remained within the safe level of sodicity since ESP was below 15, except for profile No. 12 with ESP of 15.16, indicating a slight hazard. According to the USDA(2014), the soils are TypicTomipsamments.

TABLE 2. Main characteristics for soils of the studied area.

\begin{tabular}{|c|c|c|c|c|c|c|c|c|}
\hline $\begin{array}{c}\text { Profile } \\
\text { No. }\end{array}$ & pH & $\begin{array}{l}\mathbf{E C}, \\
\mathbf{d S m}^{-1}\end{array}$ & $\begin{array}{l}\mathrm{OM} \text {, } \\
\mathrm{g} \mathrm{kg}^{-1}\end{array}$ & $\underset{\mathrm{g} \mathrm{kg}^{-1}}{\mathrm{CaCO}_{3}}$ & $\begin{array}{c}\text { Gypsum, } \\
\text { g kg }^{-1}\end{array}$ & $\begin{array}{c}\text { CEC, } \\
\text { Cmolc } \\
\mathbf{k g}^{-1}\end{array}$ & ESP & $\begin{array}{l}\text { Texture, } \\
\text { USDA triangle }\end{array}$ \\
\hline 1 & 8.09 & 1.36 & 0.53 & 0.62 & 0.72 & 4.38 & 5.72 & Sand \\
\hline 2 & 8.53 & 1.32 & 0.93 & 0.68 & 0.74 & 3.87 & 5.36 & Sand \\
\hline 3 & 8.24 & 1.17 & 0.76 & 1.06 & 0.60 & 4.27 & 4.14 & Sand \\
\hline 4 & 8.06 & 1.27 & 0.67 & 0.77 & 0.74 & 4.43 & 5.32 & Sand \\
\hline 5 & 8.00 & 1.39 & 0.82 & 0.92 & 1.09 & 4.59 & 5.08 & Sand \\
\hline 6 & 7.85 & 3.30 & 1.10 & 1.10 & 1.11 & 4.79 & 12.17 & Sand \\
\hline 7 & 8.06 & 0.79 & 0.77 & 0.95 & 0.98 & 4.32 & 2.66 & Sand \\
\hline 8 & 8.17 & 6.06 & 0.76 & 0.90 & 0.64 & 4.80 & 12.14 & Sand \\
\hline 9 & 8.49 & 4.08 & 0.50 & 0.62 & 0.84 & 4.32 & 12.24 & Sand \\
\hline 10 & 7.86 & 2.83 & 0.83 & 0.74 & 0.65 & 5.28 & 2.67 & Sand \\
\hline 11 & 8.15 & 1.36 & 0.77 & 0.75 & 0.65 & 4.87 & 2.10 & Sand \\
\hline 12 & 7.83 & 6.14 & 0.84 & 0.90 & 1.09 & 5.68 & 15.16 & $\begin{array}{l}\text { Sand } \\
\end{array}$ \\
\hline 13 & 8.21 & 2.07 & 1.00 & 1.12 & 1.38 & 4.80 & 5.11 & Sand \\
\hline 14 & 8.40 & 0.95 & 0.44 & 0.62 & 0.67 & 4.31 & 1.44 & Sand \\
\hline
\end{tabular}


Land capability classification

The land capability spatial model (LCSM) is designed for identifying capability classes for the studied area (Fig. 5). Soil properties were ranked and weighted in order to assess land capability. Thereafter, they were constructed and mapped in the geographic information system (GIS) environment. The spatial analysis was done on the GIS layers through running the LCSM to determine the capability classes and a soil capability map was produced. Based on the LCSM (Fig. 6 and Table 3), the soils belong to capability classes fair (C3) and poor (C4). The fair soils occupied an area of $208.7 \mathrm{~km}^{2}$ (20870 ha), representing $94.6 \%$ of the total area while, the poor soils occupied an area of $12.0 \mathrm{~km}^{2}$ (1200ha), representing $5.4 \%$ of the total area. The most limiting factor is soil texture (as the sand is dominant textural class). The significance of coarse soil texture is related to its implications on soil erosion susceptibility, low level of organic matter, low water holding capacity and low nutrient content and retention (Villas-Boas et al., 2016). Based on the ASLE model (Fig. 7), the fair soils occupied $117.6 \mathrm{~km}^{2}$, representing $53.3 \%$ of the total area, while the poor soils occupy $103.1 \mathrm{~km}^{2}$, representing $46.7 \%$ of the total area. A trial was done to obtain a relation through correlation coefficient analysis for some measurements (areas $/ \mathrm{km}^{2}$ ) of capability obtained from either GIS or ASEL model. After that, the data factors (y) and the correlation coefficient $r$ were calculated as shown in Fig. 8. A positive correlation was observed between the GIS and ASLE models, and hence it could be estimated that capability area form ASLE $=5.18$ GIS model.

TABLE 3. Land capability classes and areas based on the GIS and ASLE models.

\begin{tabular}{|c|c|c|c|c|}
\hline \multirow{2}{*}{ Capability class } & \multicolumn{2}{|c|}{ GIS model } & \multicolumn{2}{c|}{ ASLE model } \\
\cline { 2 - 5 } & Area $\left(\mathrm{km}^{2}\right)$ & $\%$ & Area $\left(\mathrm{km}^{2}\right)$ & $\%$ \\
\hline Fair(C3) & 208.7 & 94.6 & 117.6 & 53.3 \\
\hline Poor (C4) & 12.0 & 5.4 & 103.1 & 46.7 \\
\hline
\end{tabular}

\section{Land suitability classification}

The soils were evaluated for cultivating 12 crops, including field crops; alfalfa, peanut, sugar beet and wheat, vegetable crops; onion, tomato and watermelon, and fruit crops; citrus, date palm, fig, grape and olive (Fig. 9). The clay content is the limiting factor for crop cultivation. With slight salinity in few localities and sodicity (alkalinity) in soil profile No. 12, their occurrence could not pose a major problem. Excessive salt in such sandy soils is not concerned, where it could be leached easily (Barnard et al., 2010). The soils belong to suitable (S2) and marginally suitable (S3) classes. Peanut, tomato and date palm would be the most suitable crops in the studied area (Table 4), as the soils appear suitable (S2).

\section{Conclusion}

Land evaluation plays a vital role in land use planning and helps decision makers in initiating a suitable management of agricultural resources. In the present work, an integration of GIS and ASLE software were performed for initiating more suitable land use planning of the area under investigation. The total area of $220.7 \mathrm{~km}^{2}$ is located on the eastern side of Suez Canal belong to fair (C3) and poor (C4) capability classes. The soils of C3 represent $94.6 \%$ of the total area; meanwhile the remained area is occupied by soils of $\mathrm{C} 4$. The soils are suitable (S2) and marginally suitable (S3) for selected 12 crops. The most recommended crops would be peanut, tomato and date palm. In conclusion, the area would be promising lands for agricultural expansion to compensate the loss of arable land in Nile Delta.

Egypt. J. Soil Sci. 56, No. 3 (2016) 


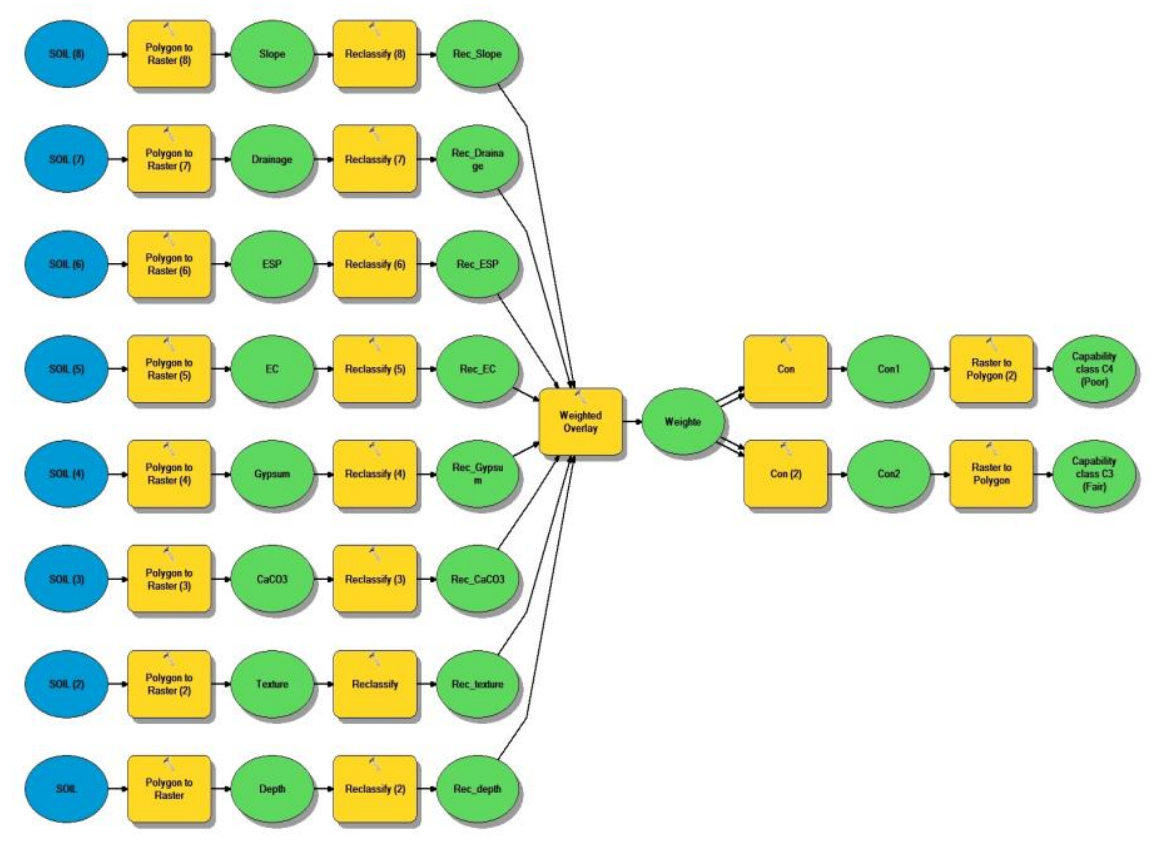

Fig. 5. Flowchart of the land capability classification spatial model.

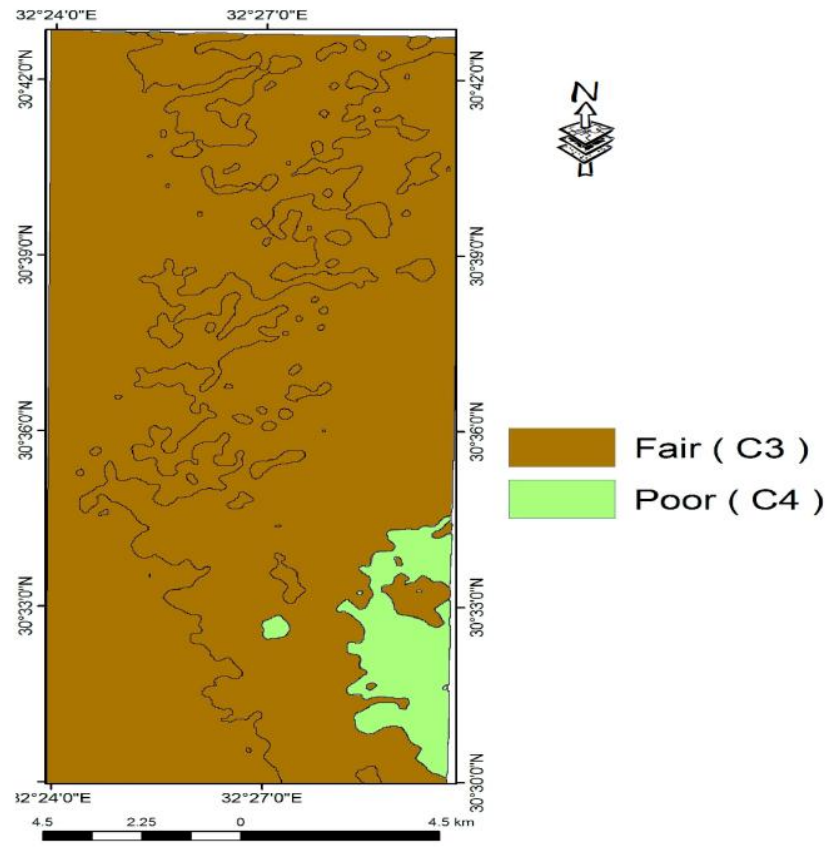

Fig. 6. Capability map based on the spatial model.

Egypt. J. Soil Sci. 56, No. 3 (2016) 


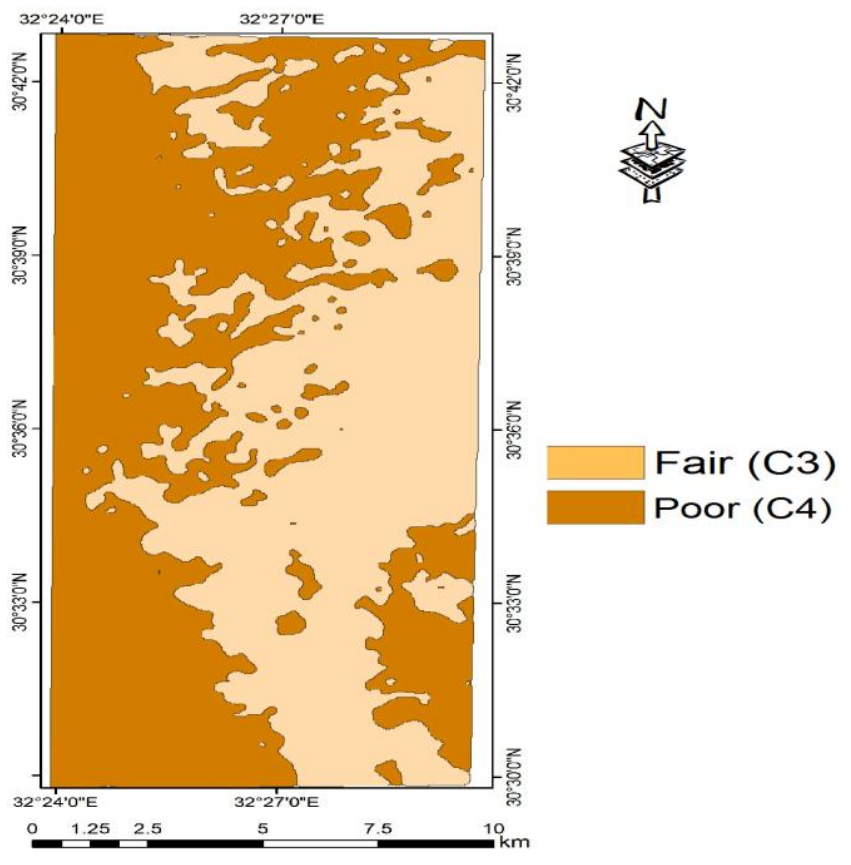

Fig. 7. Capability map based on the ASLE model.

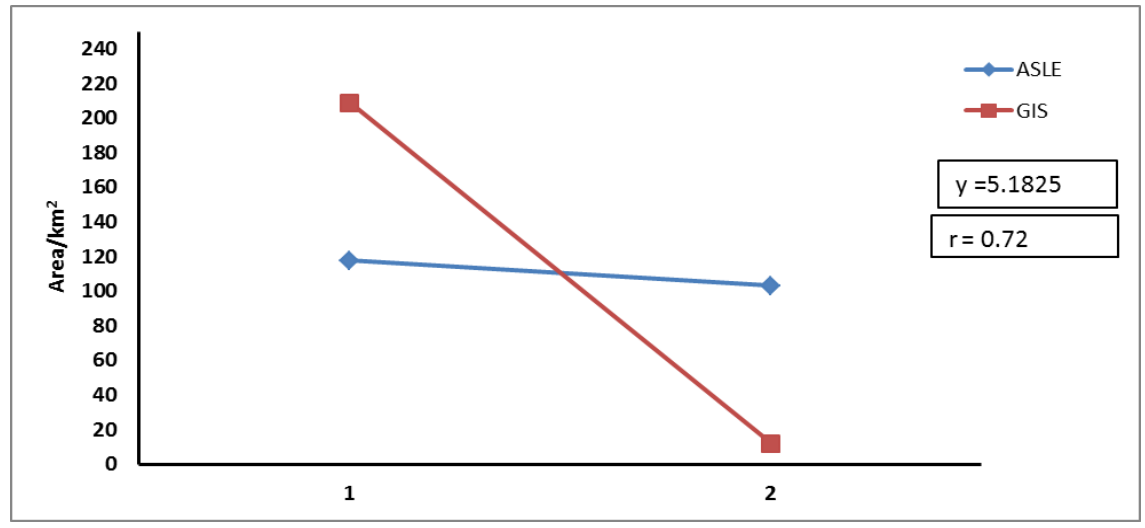

Fig. 8. Correlation between capability areas based on the GIS and ASLE models.

Acknowledgment: The authors express their deep thanks to Prof. Dr. Ali Ahmed Abd El-Salam and Prof. Dr. Hassan Hamza Abbas, Soil and Water Department, Faculty of Agriculture, Moshtohor B Benha University for their help and encouragement during the study

Egypt. J. Soil Sci. 56, No. 3 (2016) 

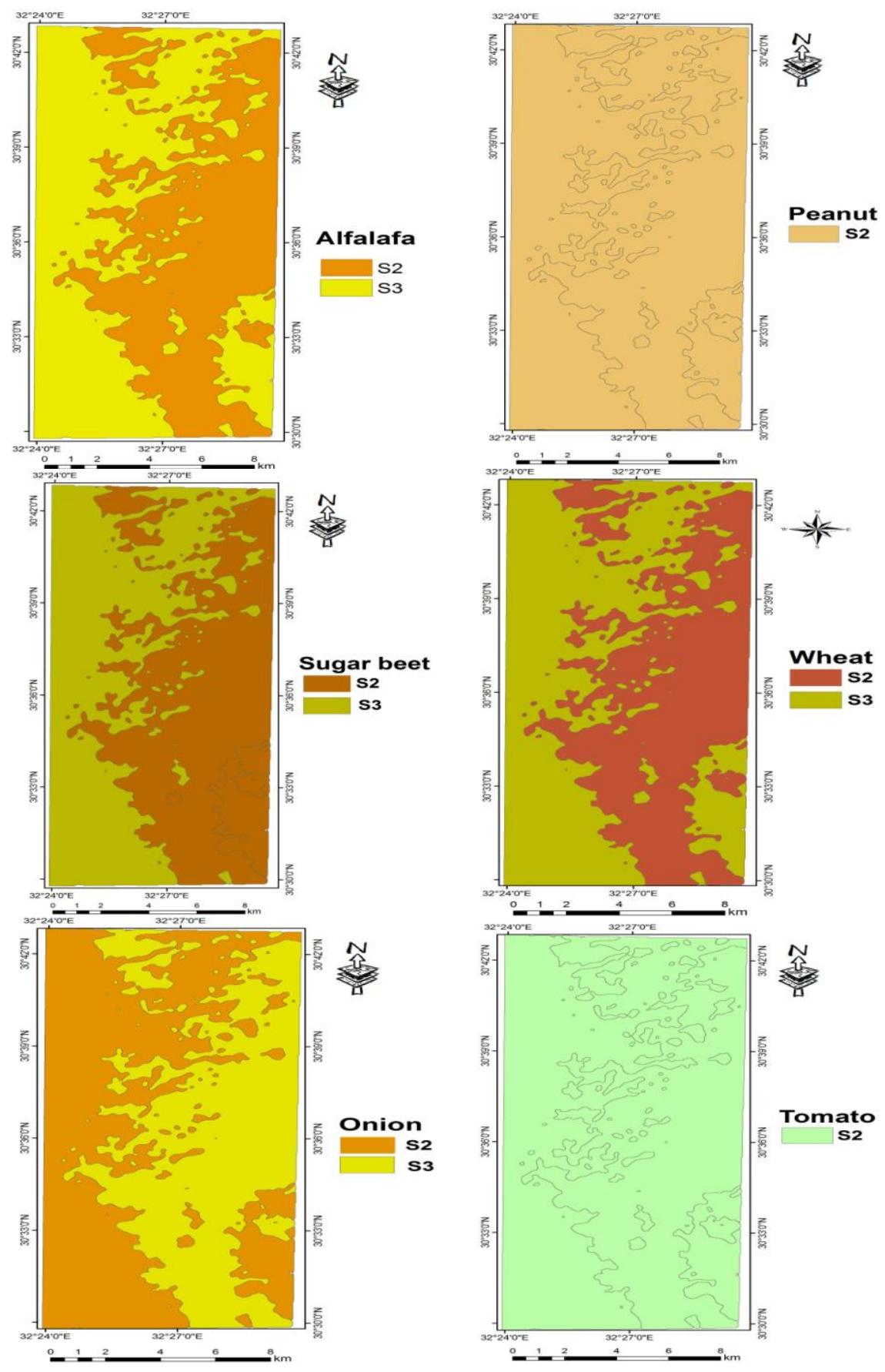

Fig. 9. Suitability maps for the selected crops in the study area.

Egypt. J. Soil Sci. 56, No. 3 (2016) 

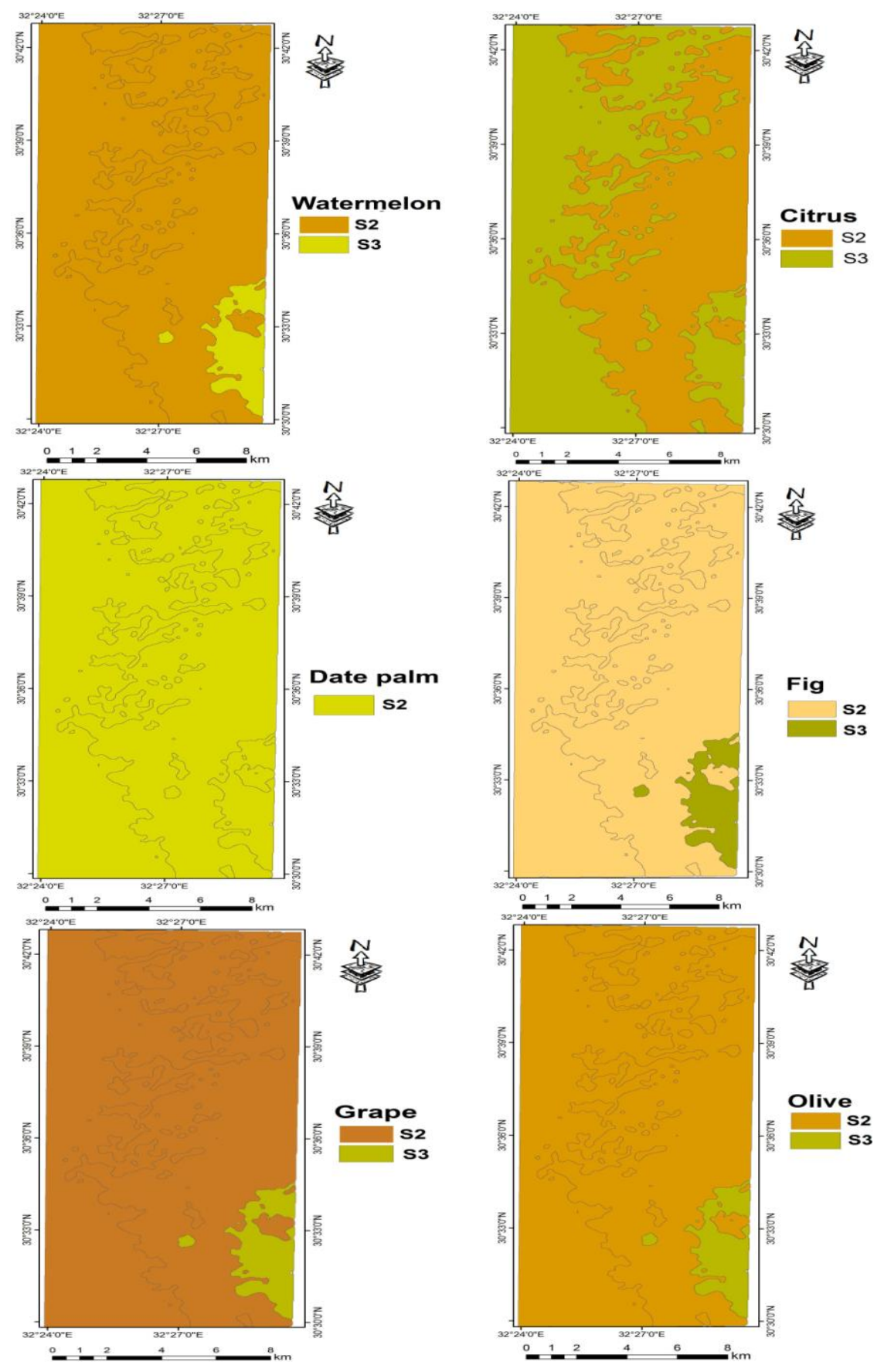

Fig.9. Cont.

Egypt. J. Soil Sci. 56, No. 3 (2016) 


\section{References}

Adriansen,H.K.(2009) Land reclamation in Egypt: A study of life in the new lands. Geofonum, 40, 664-674.

Bacic, I.LZ. (2008) Demand-driven land evaluation. In: Hartemink, A.E., McBratney, A., Mendonça-Santos, M.D.L. (Ed.)Digital Soil Mapping with limited Data. Springer Netherlands, Dordrecht.

Barnard, J.H, van Rensburg, L.D. and Bennie, A.T.P. (2010) Leaching irigated saline sandy to sandy loam apedal soils with water of a constant salinity. Irrigation Sci, 28, 191-201.

Byrmes, B.H. and Bumb, B.L. (1998) Population growth, food production and nutrient requirements. J. Crop Prod. 1,1-27.

Darwish, K, Safaa, M, Momou, A. and Saleh, S.A. (2013) Egypt: Land degradation issues with special reference to the impact of climate change. In: Heshmati, A.G., Squires, R.V.(Ed.)Combating Desertification in Asia, Africa and the MiddleEast: Proven practices. Springer Netherlands, Dordrecht.

de la Rosa, D. and van Diepen, C.A. (2002) Qualitative and quantitative land evaluation, In 1.5. Land use and land cover, InEncyclopedia of Life SupportSystem(EOLSS-UNESCO), Eolss Publishers. Oxford, UK

El-Ramady, H.R., El-Marsafawy, S.M. and Lewis, L.N.(2013) Sustainable agriculture and climate Changes in Egypt. In:Lichtfouse, E.(Ed), Sustainable Agriculture Reviews: Volume 12. Springer Netherlands, Dordrecht.

Estefan, G., Sommer, R. and Ryan, J. (2013) Methods of Soil, Water and Plant Analysis: A Manual for The West Asia and North Africa Region, $3^{\text {td }}$ ed. Int. Center Agric. Res. In Dry Areas (ICARDA), Beint, Lebanon

ESRI (2014) Arc Map version 10.2.2 user manual. ESRI, 380 New York Street, Redlands, Califomia, 92373-8100, USA

FAO (1976) A framework for land evaluation. Soil Bull. No. 32 Food and Agriculture Organization (FAO) of the United Nations, Rome, Italy.

FAO (2006) Guidelines for soil profile description. Food and Agriculture Organization (FAO) of the United Nations, Rome, Italy.

FAO (2007) Land evaluation. Towards a revised framework. Land and Water Disc. Paper No. 6 Soil Bull. No. 32 Food and Agriculture Organization (FAO) of the United Nations, Rome, Italy.

Godfray, H.C.J, Beddington, J.R, Crute, I.R, Haddad, L, Lawrence, D, Muir, J.F, Pretty, J, Robinson, S, Thomas, S.M. and Toulmin, C. (2010) Food security:the challenge of feeding 9 billion People. Science, 327, 812-818.

Ismail, H.A., Morsy, LM, El-Zahaby, E.M. and El-Nagar, FS. (2001) A Developed expert system for land use planting by coupling and modeling.Alex. J.Agric. Res. 46(3), 141-154

ITT(2014) ITT corporation ENVI5.1 software, 1133 Westchester Avenue, White Plains, New York 10604, USA.

Kalogirou,S.(2002) Expert systems and GIS: an application of land suitability evaluation. Computers Environ. Urban Syst., 26, 89-112.

Lawrence, W.T, Imhoff, M.L, Kerle, N. and Stutzer,D. (2002) Quantifying urban land use and impact on soils in Egypt using diumal satellite imagery of theEarth surface. Int. J. Remote Sens., 23, 3921-3937. 
Li,L, Zhao,J.and Yuan, T.(2011) Study on approaches of land suitability evaluation for crop production using GIS. In: Li, D., Liu, Y., Chen, Y. (Ed), Computer and Computing Technologies in Agriculture IV: 4th IFIP TC 12 Conference, CCTA 2010, Nanchang, China, October 22-25, 2010, selected papers, Part II. Springer. Berlin Heidelberg, Berlin, Germany.

Lillesand. T.M. and Kiefer, R.W (2007) Remote Sensing and Image Interpretation, $5^{\text {th }}$ ed. Paperback, JohnWiley, New York,p. 820.

Mohamed, E, Belal, A. and Saleh, A. (2013) Assessment of land degradation east of the Nile Delta, Egypt using remote sensing and GIS techniques. Arab J. Geosci., 6, 2843-2853.

Mueller, L, Schindler, U., Mirschel, W, Shepherd, T.G, Ball, B.C, Helming, K, Rogasik, J, Eulenstein, F. and Wiggering, H. (2010) Assessing the productivity function of soils. A review. Agron. Sustain. Dev., 30, 601614.

Shalaby, A. and Moghanm, FS. (2015) Assessment of urban sprawl on agricultural soil of northem Nile Delta of Egypt using RS and GIS. Chinese Geogr. Sci., 25,274-282.

Sharififar,A. (2012) Assessment of different methods of soil suitability classification for wheat cultivation. J.Agrobiol, 29,47-54.

Sys, C, Van Ranst, E, Debaveye, J. and Beernaert, F. (1993) Land evaluation. Part III. Crop requirements. Agricultural publications No. 7. General administration for development cooperation, Brussels, 199p

U.S. Department of Agriculture (2014) Keys To Soil Taxonomy, $12^{\text {th }}$ ed. USDA-Natural Resources Conservation Service, Washington, DC, USA.

Villas-Boas, P.R, Romano, R.A, Franco, M.A.D, Ferreira, E.C, Ferreira, E.J., Crestana, S. and Milori, D. (2016) Laser-induced breakdown spectroscopy to determine soil texture: A fast analytical technique. Geoderma, 263, 195-202.

Vink, N. (2012) Food security and African agriculture. South African J. Int. Affairs, 19, 157-177.

(Received: 28/4/2016;

accepted:26/10/2016)

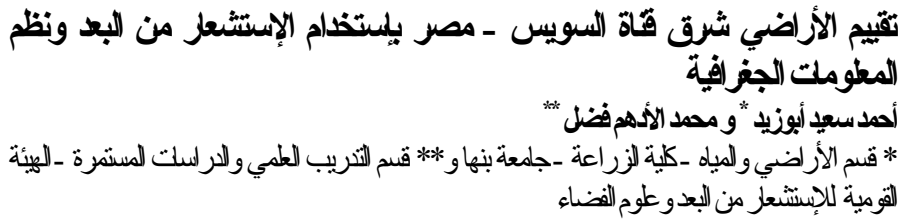

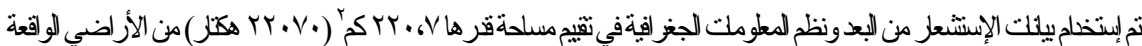

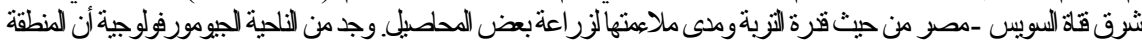

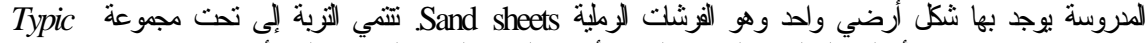
Torripsamments

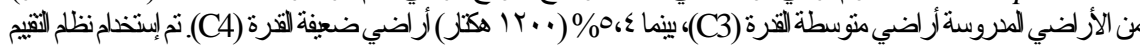

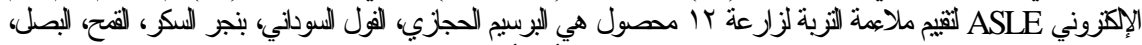

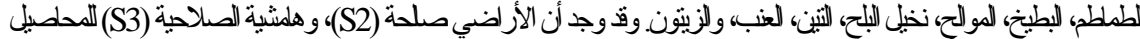

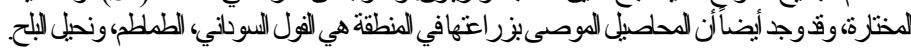

Egypt. J. Soil Sci. 56, No. 3 (2016) 
